\title{
Comparison of Nine Planting Distances on the Yield of Pineapple Variety PR 1-67'
}

\author{
Oscar D. Ramírez and Héctor Gandía ${ }^{2}$
}

\begin{abstract}
The effect of nine planting distances on total and marketable yields, fruit weight, number of slips, and quality of the juice was studied on pineapple variety PR 1-67.

Planting density varied from 59,595 to 31,377 plants per hectare.

Total and marketable fruit yields increased with increasing plant density.

No significant effect on mean fruit weight was observed. The production of slips increased with a decrease in plant density. No significant effect was observed on the quality of the juice.

From this test it can be concluded that treatments 51,625 piants/ha, 43,937 plants/ha, and 43,047 plants / ha with marketable yields of 86,75 and $74 \mathrm{t} / \mathrm{ha}$, respectively, in the plant crop and $45.43,37.78$ and $41.32 \mathrm{t} / \mathrm{ha}$, respectively, in the ratoon crop would be adequate for good yields of fruit and would yield at least one slip per plant for field replacement in the next plant crop.
\end{abstract}

\section{INTRODUCTION}

PR 1-67 $(6,7)$ a new pineapple variety developed at the Plant Breeding Department of this Station has been under study with regard to the agronomical practices it requires for high yields.

In a preliminary experiment (8) with three planting distances, the highest yield (70.38 t/ha) was obtained when planting distances, were 61 $\mathrm{cm}$ between rows and $30.5 \mathrm{~cm}$ within the row, with a passage way of $137.16 \mathrm{~cm}$ between the double rows. These results led to a new experiment, in which nine planting distances were tested. The distance between the two row beds was changed to determine the viability of a very close planting as well as a close spacing within the row, including that recommended for the Red Spanish variety, which is $28 \mathrm{~cm} \mathrm{(3).} \mathrm{The} \mathrm{results} \mathrm{of}$ these tests are presented here.

\section{MATERIALS AND METHODS}

Pineapple variety PR 1-67 was planted in a Bayamón sandy clay loam on the Land Authority Farm at Manatí. The field was treated prior to planting to control white grubs and ants, and with DD (99 gal/ha) to control nematodes (2).

The experimental design used was a balanced lattice with nine treatments and four replicates.

The aisle spaces between the pairs of rows were $128 \mathrm{~cm}, 102 \mathrm{~cm}$, and 82

${ }^{\mathrm{t}}$ Manuscript submitted to Editorial Board October, 1980.

${ }^{2}$ Plant Breeder and Horticulturist, respectively, Agricultural Experiment Station, Mayagüez Campus, University of Puerto Rico, Río Piedras, P. R. 
$\mathrm{cm}$. In each of these distances, the plants in the row were planted 25.4, 30.5 and $35.6 \mathrm{~cm}$ apart making a total of 9 different treatment combinations. The distance between rows $(50.8 \mathrm{~cm})$ was the same for all the treatments.

Plot size was $7.62 \mathrm{~m}$ by $3.05 \mathrm{~m}$. Rows were $7.62 \mathrm{~m}$ long. Plots were planted in four double rows, in five double rows, and in a six double rows. The spaces between sets of double rows were $128 \mathrm{~cm}, 102 \mathrm{~cm}$, and $83 \mathrm{~cm}$, respectively. The outside single row on each side of a plot and the end plants on each row were considered as borders (table 1.).

The experiment was established February 25-27, 1969. Fertilizing was the regular plantation practice, that is, monthly foliar applications with a boom sprayer that covers the area uniformly regardless of the number of plants per acre.

Flowering was forced at $102 / 3$ months from planting, and the fruit was harvested about 6 months later, from May 12 to June 8, 1970.

The fruits of the first and second crop were harvested when ripe, their weights recorded and the statistical analysis of the data performed.

In order to measure the effect on the yield of marketable fruits, on the first crop the fruits were classified as to size by their widest diameter. This dimension determines the number of similar-size fruits that will go into the fresh fruit marketing crate. The sizes used in the estimate were 6 's, 8's, 9's and 12's. Sizes smaller than 12's were not included in the calculations and were considered as culls. Sizes 9's and 12's are preferred by the New York market, 9's are preferred by the cannery, and the 6's and 8 's by the local market.

\section{RESULTS AND DISCUSSION}

\section{FIRST CROP}

\section{Effect of planting distance on fruit yield}

Table 1 presents yield data. The highest fruit tonnage $(97.13 \mathrm{t} / \mathrm{ha})$ was produced by the treatment with the largest number of plants, and the lowest yield $(58.04 \mathrm{t} / \mathrm{ha})$ was produced by the treatment with the lowest number of plants. Similar results with varieties other than PR 1-67 have been reported by other workers: Pennock (5), González Tejera (4), and Ramírez (8), in Puerto Rico, Su (9) in Taiwan, Wee (10), in Malaysia and Cannon (1) in Australia. Correlation analysis showed a highly significant negative correlation of plant area and fruit yield (fig. 1).

\section{Effect of planting distances on the yield of marketable fruits}

The fruits produced with each treatment were classified as to size.

Table 1 shows that the lowest number of crates of marketable fruit 
TABLE 1.-Planting distances of the nine treatments with the corresponding plants per hectare and the equivalent number of square meters per plant and yield of fruit, mean fruit weight, crates of marketable fruits per hectare and number of slips per plant

\begin{tabular}{|c|c|c|c|c|c|c|c|c|c|}
\hline \multirow[t]{2}{*}{ Treatment } & \multicolumn{3}{|c|}{$\begin{array}{l}\text { Double row planting system } \\
\text { Spacing between }\end{array}$} & \multirow[t]{2}{*}{ Plants/ha } & \multirow[t]{2}{*}{ Area/plant } & \multirow[t]{2}{*}{ Yield/ha } & \multirow{2}{*}{$\begin{array}{l}\text { Mean } \\
\text { wt/fruit }\end{array}$} & \multirow[t]{2}{*}{ Crates/ha ${ }^{1}$} & \multirow[t]{2}{*}{ Slips/plant } \\
\hline & Plants & Rows & Double rows & & & & & & \\
\hline & $\mathrm{cm}$ & $\mathrm{cm}$ & $\mathrm{cm}$ & & $m^{2}$ & $T$ & $k g$ & & \\
\hline 1 & 25.40 & 50.80 & 128.42 & 43,937 & .2278 & $75.57 \mathrm{c}^{2}$ & 1.72 & 4,307 & 1.07 \\
\hline 2 & 30.48 & 50.80 & 128.42 & 36,643 & .2729 & $65.22 \mathrm{c}$ & 1.78 & 3,832 & 1.22 \\
\hline 3 & 35.36 & 50.80 & 128.42 & 31,377 & .3178 & $58.04 \mathrm{~d}$ & 1.85 & 3,349 & 1.39 \\
\hline 4 & 25.40 & 50.80 & 101.60 & 51,625 & .1930 & $86.21 b$ & 1.67 & 4,667 & 0.95 \\
\hline 5 & 30.48 & 50.80 & 101.60 & 43,047 & .2323 & $74.04 \mathrm{~b}, \mathrm{c}$ & 1.72 & 4,259 & 1.08 \\
\hline 6 & 35.36 & 50.80 & 101.60 & 36,900 & .2710 & $65.68 \mathrm{c}$ & 1.78 & 3,852 & 1.23 \\
\hline 7 & 25.40 & 50.80 & 81.28 & 59,595 & .1678 & $97.13 \mathrm{a}$ & 1.63 & 4,939 & 0.86 \\
\hline 8 & 30.48 & 50.80 & 81.28 & 49,677 & .2013 & $83.45 b$ & 1.68 & 4,586 & 0.97 \\
\hline 9 & 35.36 & 50.80 & 81.28 & 42,571 & .2349 & $73.64 \mathrm{~b}, \mathrm{c}$ & 1.73 & 4,232 & 1.09 \\
\hline
\end{tabular}

${ }^{1}$ Crates of $6,8,9,12$ fruits with an approximate gross weight of $18 \mathrm{~kg}$.

${ }^{2}$ Values with the same letter do not differ significantly at $P=.05$, according to Duncan's multiple range test. 
$(3,349)$ per hectare corresponded to treatment 3 , with the lowest number of plants; and inversely, the highest number of crates of marketable fruit $(4,939)$ were produced by treatment 7 , with the highest number of plants per hectare. Figure 2 shows a linear regression relationship between the planting distance and the number of crates produced per hectare. The number of crates increased significantly with a reduction in the area per plant. This was also observed by Cannon (1) in Australia working with

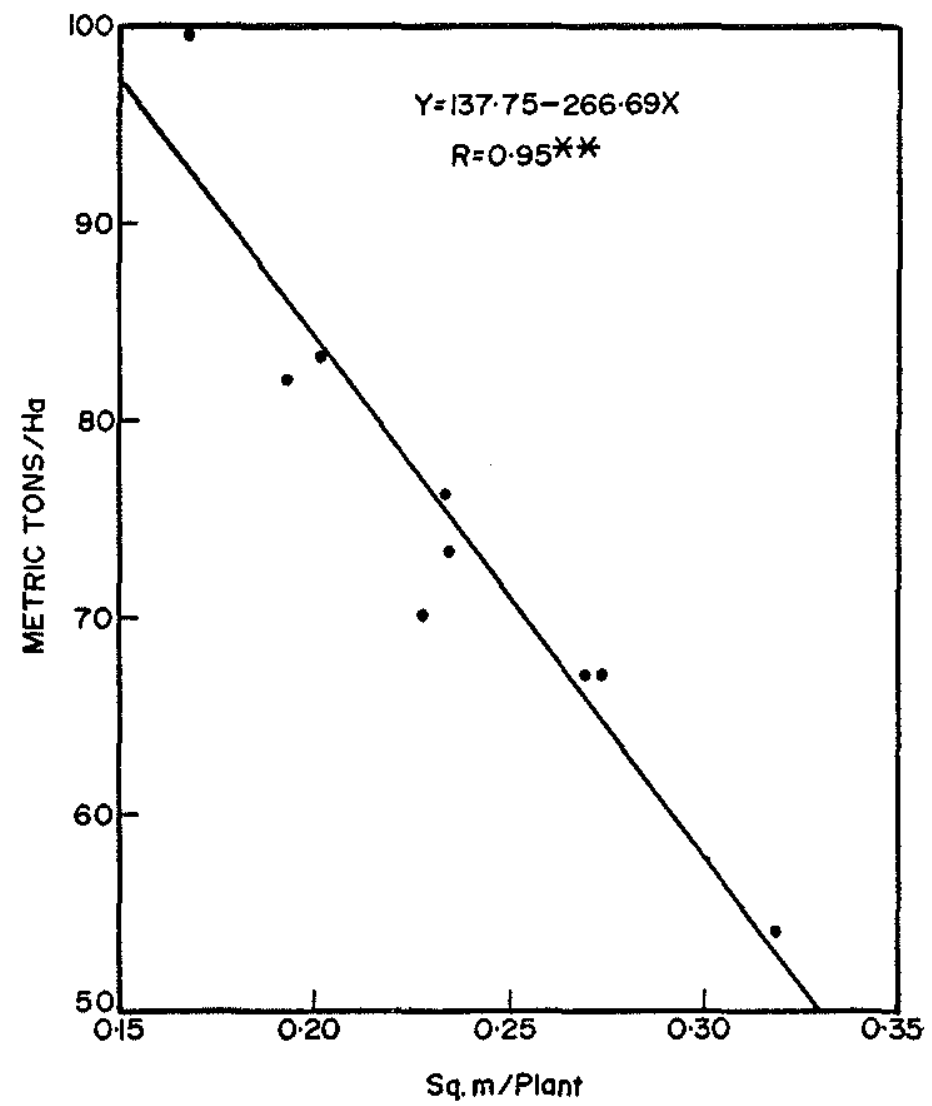

Fig. 1.-Effect of plant density on fruit yield.

Smooth Cayenne, who says that yields increase progressively with reduction in spacing between plants.

Effect of planting distance on mean fruit weight

Table 1 shows that fruit weight produced with the different planting distances varied from $1.63 \mathrm{~kg}$ to $1.85 \mathrm{~kg}$ per fruit. Although the lower mean fruit weight corresponded to the treatment with the highest number 
of plants per hectare, and the higher mean fruit weight corresponded to the treatment with lowest number of plants per hectare, these differences are not statistically significant. This finding is in line with the results reported by Cannon (1) and González Tejera (4), who also observed a small nonsignificant reduction in the mean fruit weight with increasing population.

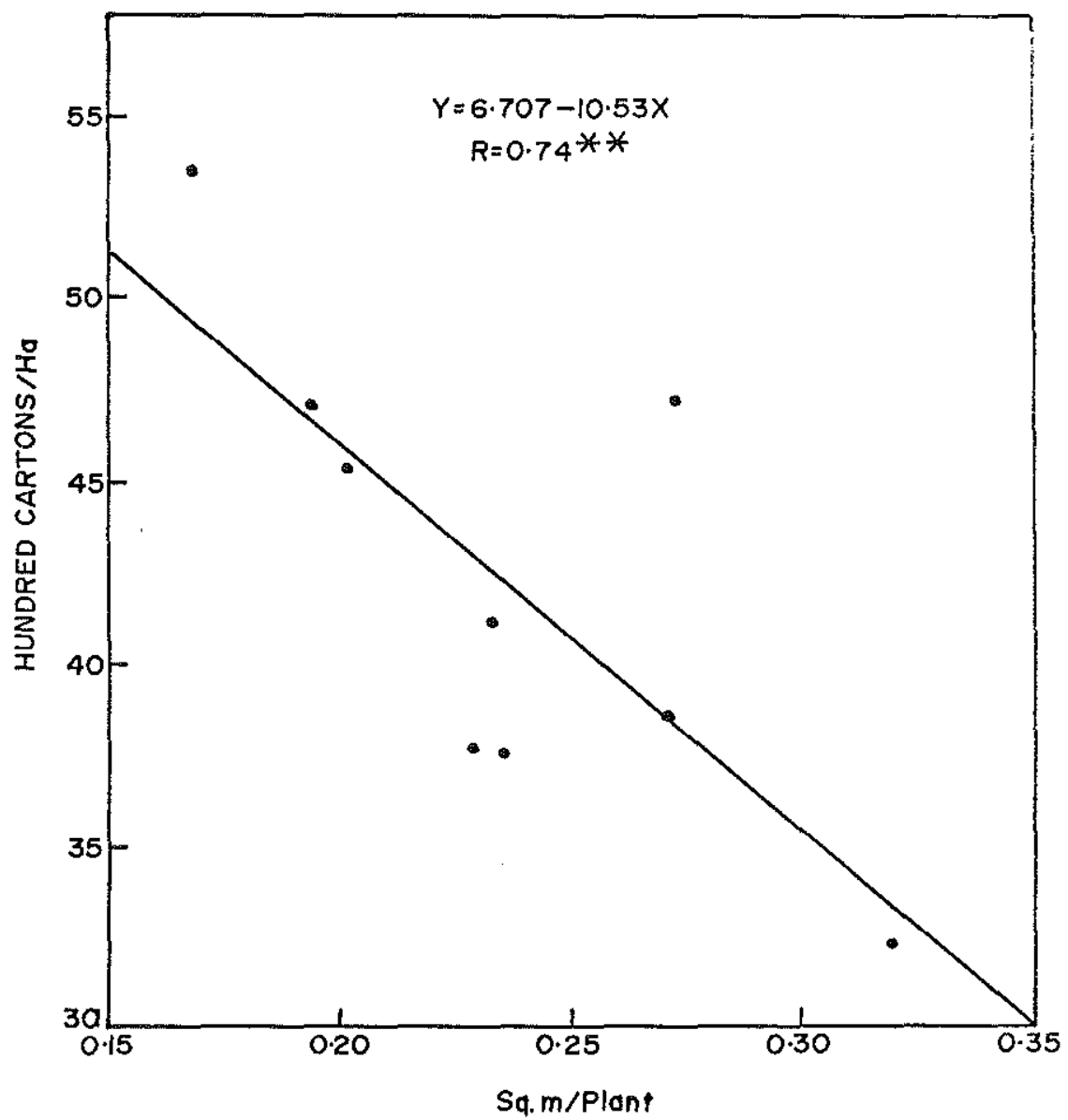

FIG. 2.-Effect of plant density on marketable fruits.

Effect of planting distance on the number of slips

In this experiment the production of slips per plant varied in the nine treatments from 0.86 to 1.39 slips per plant, (table 1). Slip production decreased as plant density increased. This relationship is highly significant (fig. 3). This was also observed by Su (9) working with Smooth Cayenne and by González Tejera (4) with PR 1-67. In evaluating any 


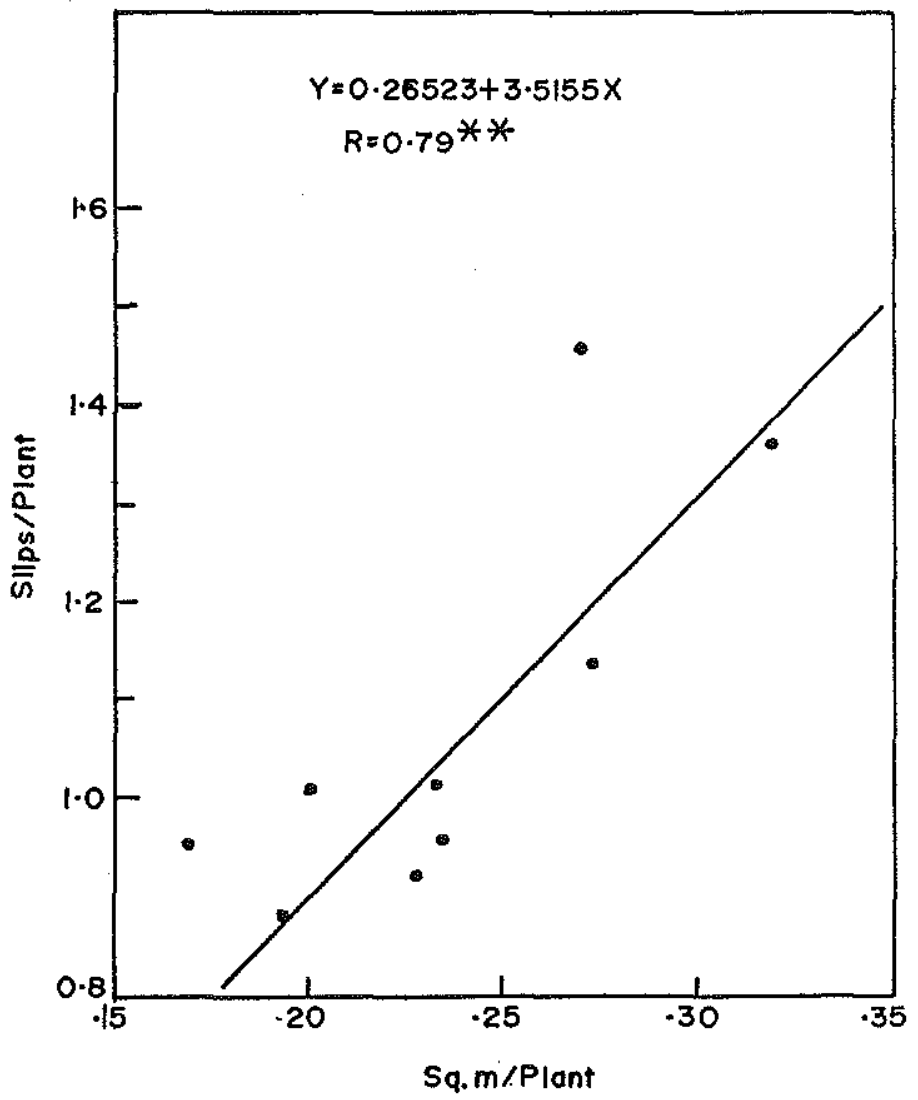

FIG, 3,-Effect of plant density on slip production.

pineapple variety, the number of slips produced per plant is very important, since slips are needed to replant the field.

Effect of the planting distance on the total acidity, Brix and $p H$

Table 2 presents data as to acidity, Brix and $\mathrm{pH}$. None of the treatments exerted any significant effect upon fruit quality.

The quality of the juice was not affected significantly by varying plant density. This was also observed by González Tejera (4).

\section{SECOND CROP (RATOON)}

Effects of treatments on fruit weight and yield

Statistical analysis of the average fruit weight (table 2) indicated that there were no significant differences between the effect of the different planting distances on fruit weight. Average fruit weight ranged from 0.99 to $0.86 \mathrm{Kg}$. 
As to yield (table 3), there were significant differences due to varying spacing. The highest yield was obtained with the highest plant density. It was observed that yield increased as the number of plants increased. Since fruit size was about the same in all treatments, yield was directly proportional to the number of fruits harvested, which is proportional to the number of plants per hectare. This was also observed by Su (9) working with variety Smooth Cayenne and by Wee (10) with variety Singapore Spanish.

TABLE 2.- Effect of population on the citric acid, total solids in the juice (Brix and pH) of the pineapple

\begin{tabular}{cccc}
\hline Plant/ha & Citric acid $\mathrm{mg} / \mathbf{1 0 0} \mathrm{ml}$ & Total solids (Brix) & pH \\
\hline 43,937 & 709.77 & 17.30 & 2.97 \\
36,643 & 690.11 & 16.64 & 3.02 \\
31,377 & 815.00 & 16.88 & 2.96 \\
51,625 & 920.55 & 17.25 & 3.00 \\
43,047 & 901.11 & 16.48 & 2.99 \\
36,900 & 697.22 & 17.52 & 3.03 \\
59,595 & 817.77 & 16.75 & 3.01 \\
49,677 & 779.55 & 16.87 & 2.94 \\
42,571 & 827.88 & 16.86 & 3.03 \\
\hline
\end{tabular}

TABLE 3.-Pineapple yield of the second crop (ratoon)

\begin{tabular}{cccl}
\hline Treatment & Plants/ha & Mean fruit weight & Yield/ha \\
\hline 1 & & $k g$ & \\
2 & 43,937 & 0.86 & $37.78 \mathrm{c}, \mathrm{d}^{\mathbf{1}}$ \\
3 & 36,643 & 0.91 & $33.34 \mathrm{c}, \mathrm{d}$ \\
4 & 31,377 & 0.90 & $28.23 \mathrm{~d}$ \\
5 & 51,625 & 0.88 & $45.43 \mathrm{~b}$ \\
6 & 43,047 & 0.96 & $41.32 \mathrm{~b}, \mathrm{c}$ \\
7 & 36,900 & 0.97 & $35.79 \mathrm{~b}, \mathrm{c}$ \\
8 & 59,595 & 0.99 & $58.99 \mathrm{a}$ \\
9 & 49,677 & 0.89 & $44.21 \mathrm{~b}$ \\
\hline
\end{tabular}

\footnotetext{
${ }^{1}$ Values with the same letter do not differ significantly at $\mathrm{P}=.05$, according to Duncan's
} multiple range test.

From the results of this test it can be concluded that plant densities of 51,625 plants/ha, 43,937 plants/ha and 43,047 plants/ha with a yield of 86,77 and $76 \mathrm{t} / \mathrm{ha}$, respectively, in the plant crop and $45.43,37.78$ and $41.32 \mathrm{t} / \mathrm{ha}$, respectively, in the ratoon crop, would be adequate for good yields of fruit and would yield at least one slip per plant for field replacement in the plant crop.

It appears that the narrower aisle is not adequate for variety PR 1-67 because the stiffness and spinosity of its leaves make cultivation and harvesting difficult. 
In general, closer spacing than the one used at present has various advantages with variety PR 1-67. Among the most important are higher yields without reduction in quality, weed growth suppression, weeding cost reduction and production of propagating material that makes it possible to expand the planting area.

\section{RESUMEN}

Se investigó el efecto de nueve densidades de siembra sobre el rendimiento total, número de huacales de fruta comercial, el tamaño medio de las frutas producidas, el número de hijuelos de corona por planta y la calidad del jugo en la variedad de piña PR 1-67. Se usó el sistema corrienté de doble hilera, con $50.8 \mathrm{~cm}$ de separación. Esta distancia se mantuvo constante en todos los tratamientos. Las distancias usadas entre las plantas en la hilera fueron de $25.4,30.5$, y $35.6 \mathrm{~cm}$. Las distancias entre cada par de hileras fueron de 81,102 , y $128 \mathrm{~cm}$.

El número de plantas por hectárea varió entre 13,000 y 60,000 . Los rendimientos aumentaron según aumentó el número de plantas por hectárea. Ni el peso medio de las frutas, ni la calidad del jugo fueron significativamente afectados al variar las distancias de siembra. La producción de hijuelos se redujo al aumentar la densidad de siembra.

Se encontró que las mejores densidades para la siembra de esta variedad son $51,625,43,937$ y 43,047 plantas por hectárea. La producción obtenida con estas densidades en la siembra de plantilla fue de 86 , 75 y 74 toneladas por hectárea, respectivamente, y en la siembra de retoño, 45, 37 y 41 toneladas/hectárea. Estas producciones de fruta son altas, y a la misma vez se obtiene material de propagación para continuar las siembras de esta variedad.

\section{LITERATURE CITED}

1. Cannon, R. C., 1957. Closer spacing of pineapples. Queensl. Agric. J. 83 (1): 575-78.

2. Conjunto Tecnológico para la Producción de Piña, 1976. Publ. 106, Esta. Exp. Agric. Univ. P. R., Río Piedras, P. R.

3. Gandía, H. y Samuels, G., 1958. Cultivo y Elaboración de la Piña en Puerto Rico, Bol. 145, Fsta. Exp. Agric. Univ. P. R., Río Piedras, P. R.

4. González-Tejera, E., Efecto del Peso de la "semilla", la Distancia de Siembra y la Edad al Momento de Provocar la Floración sobre la Producción de la Piña, Ananas comosus (L.) Merr. var. P R 1-67. Resultados Preliminares. Reunión Anual de la Sociedad Americana de Horticultura (Región del Caribe) XXVII, Mazatlán, México, 1979. In press.

5. Pennock, W., 1956. Efecto de las Distancias de Siembra sobre el Tamaño y la Calidad de la Piña, Rev. Agric. P. R., Dep. Agric. 44 (1) 97-9.

6. Ramírez, O. D., Gandía, H., and Vélez Fortuño, J., 1970. Two new pineapple varieties for Puerto Rico, J. Agric. Univ. P. R. 54 (3): 417-28.

7.,-- and - 1972. P R 1-67, A new pineapple selection, Fruit Varieties and Hort. Dig. 26 (1): 13-5. 
8. - , and - 1976. Comparison of three planting distances and fertilizer applications on the yield of pineapple variety P R 1-67, J. Agric. Univ. P. R, 60 (1): 31-5.

9. Su, N. R., 1957. Spacing and fertilizer levels as two dominant factors in the production of pineapples, J. Agric. Ass. China (New Series) 17: 18-66.

10. Wee, Y. C., 1969. Planting density trials with A. comosus (L.) Merr. var. Singapore Spanish, Malays. Agric. J. 47 (2): 164-74. 